\title{
Effect of Wet Rice Distillers Grain and Solubles on Milk Production and Composition in Lactating Cows
}

\author{
M.C. Pakhira* and P. Biswas \\ Department of Livestock Farm Complex, F/O-VAS (Mohanpur, Nadia), West Bengal \\ University of Animal and Fishery Sciences, Kolkata-700 037, India \\ *Corresponding author
}

\section{A B S T R A C T}

Keywords

Wet Rice Distiller Grains and Soluble (WRDGS), Solid Not Fat (SNF),

Lactating cows

Article Info

Accepted:

12 August 2018

Available Online:

10 September 2018
A study was conducted in lactating dairy cows to evaluate the effect of wet rice distillers' grain and soluble (WRDGS) on milk production and composition. Forty (40) lactating Jersey cows, in mid-lactation with an average live weight $350 \mathrm{~kg}$ and producing $8-9 \mathrm{~kg}$ milk daily were divided into two groups consisting of twenty animals in each group having 4 replicates with 5 animals in each. The control group cows were individually fed $6.0 \mathrm{~kg}$ concentrate and $4.0 \mathrm{~kg}$ straw whereas treatment group cows were fed $4.0 \mathrm{~kg}$ concentrate, $5.0 \mathrm{~kg}$ straw and $4.0 \mathrm{~kg}$ wet rice distiller grains and soluble. The results indicated that milk yield, milk fat, milk protein and lactose percentage was not significantly $(p>0.05)$ affected by feeding of WRDGS. However, total solid and SNF percentage was significantly increased in the experimental group. The WRDGS fed cows consumed less dry matter without affecting its milk production, reflecting better economic gain per animal in experimental feeding than control.

\section{Introduction}

Distiller's grain is a co-product of ethanol industry in which corn is being used for ethanol production in the United States (Birkelo et al., 2004). Rice distillers' grain (Rice cake) is a by-product of the processing of rice grain which is produced from the distillation of fermented rice, an important byproduct of the distillers industries in Asian countries. It contains a valuable source of supplemental protein with high rumen degradability (Warner, 1970). It also contains other nutrients recovered from fermented rice. These include low soluble carbohydrate and fibre, high fat and factor (live yeast) that stimulate cellulose digestion in the rumen. The nutrient content and feeding value of rice distillers' grain is expected to be different from commercially available source since the ingredients for rice wine production include primarily rice grain with only a little amount of corn.

Rice distillers' grain as often fed as wet to avoid drying cost. Both wet and dried corn distillers grain supported similar milk production and composition (Al-Suwaiegh et al., 2002). There is dearth of information on the feeding and nutritional value of this important by-product from rice. Therefore, the present study was planned to evaluate the use 
of wet rice cake as a part of concentrate in lactating dairy cows based on milk yield, composition, feed intake and economic gain.

\section{Materials and Methods}

A sixty days feeding trial was conducted on forty (40) lactating Jersey cows in their midlactation with an average live weight $350 \mathrm{~kg}$ and producing $8-9 \mathrm{~kg}$ milk, at a private Dairy farm near Dum Dum Airport, Kolkata. The cows were divided into two groups consisting twenty animals in each group. Each group had four replicates with five animals in each. One common concentrate diet was formulated comprising de-oiled rice bran (DORB), gram chuni, arhar chuni, crushed maize, pea husk, mineral mixture and common salt. The ingredient composition and their cost are presented in table 1 . The concentrate diet and roughage (straw) was fed to both control and experimental animals separately and only a portion (one-third) of concentrate is replaced by wet rice cake.

The cows were dewormed monthly during the experimental period and confined for individual feeding. After one week of adaptation period, the cows were subjected to a sixty days feeding trial. These cows were individually fed $6.0 \mathrm{~kg}$ concentrate diet and $4.0 \mathrm{~kg}$ straw in control group whereas the treatment group was offered $4.0 \mathrm{~kg}$ of concentrate, $4.0 \mathrm{~kg}$ of wet rice cake (about $75 \%$ moisture) and $5.0 \mathrm{~kg}$ straw. Water was provided individually with an automatic channel type drinker.

The cows were milked twice daily at 6.00 and $18.00 \mathrm{hr}$. During the feeding period dry matter intake and milk yields were recorded daily. The dry matter intake was calculated from the amount of dry matter present in feed offered, subtracted from the dry matter present in the refusal. Monthly milk samples were collected for chemical analysis of milk fat, milk protein,
SNF, milk total solids, lactose and ash content. Economic gain per animal was calculated on the basis of feed cost of each group animals. Both cost of wet rice cake and straw was Rs. 5.00 per $\mathrm{kg}$.

Total fat percentage of milk was determined by Gerber method cited in ISI (1977). Milk protein percentage was estimated by conventional micro-Kjeldahl digestion and distillation procedure (AOAC, 1980). Percentage of lactose was assayed by Picric acid method as described by Perry and Doan (1950). Gravimetric method as cited in ISI (1981) was followed for determining the total solid content in milk. Estimation of ash (mineral) content was done by the method described in the manual of Dairy Chemistry (1962) published by Nation Dairy Research Institute, Karnal. The data collected were subjected to statistical analysis with GLM procedure of SPSS (Version 10.0) with Least Square ANOVA on cow, group and period.

\section{Results and Discussion}

The effect of WRDGS inclusion in the diet of lactating cows and their performances is presented in Table. 2. The dry matter intake was significantly reduced $(\mathrm{P}<0.05)$ in WRDGS group in both $1^{\text {st }}$ and $2^{\text {nd }}$ month. The decrease in DM intake was $0.62 \mathrm{~kg}$ for the $1^{\text {st }}$ month and $0.51 \mathrm{~kg}$ for the $2^{\text {nd }}$ month as compared to control. The dry matter intake did not improve in second month both in control and treatment group. The present finding corroborates the findings of Schingoethe et al., (1999) who reported significantly $(\mathrm{P}<0.05)$ lower DMI in corn distiller's grain fed Holstein cows than control. Hippen et al., (2003) and Kalscheur et al., (2004) also reported that the moisture content added to the diet by feeding wet distillers grains and soluble at $30 \%$ of dry matter decreased dry matter intake. Haung et al., (1999) noted that dry matter intake was progressively depressed 
$(\mathrm{p}<0.05)$ when the level of dried rice distiller's grain inclusion in the diet increased. Birkelo et al., (2004) found significant $(\mathrm{P}<0.01)$ decrease in dry matter intake when Holstein cows were fed with corn distiller's grain.

Milk yield per day was not significantly $(\mathrm{P}>0.05)$ affected by feeding wet rice distiller's grain and soluble (WRDGS) in lactating cows. Milk yield was comparatively higher (8.55 vs.8.70 kg/day) and (8.65 vs.8.85 $\mathrm{kg}$ /day) during first month and second month both in control and treatment group, respectively. Higher milk yield in treatment group might be due to higher protein content in rice distiller's grain and live yeast from WRDGS which helped in nutrient utilization. The present findings corroborated with the results of Power's et al., (1995) who used soybean meal and distillers grain diet as protein sources and found diet containing DDGS yielded $0.80 \mathrm{~kg}$ more milk/day than control in lactating cows fed soybean meal diets.

Anderson et al., (2006) also found higher milk yield by feeding 10 or $20 \%$ wet and dry distillers' grains plus soluble than control but the level and form (wet or dry) did not show any significant difference in milk yield. Kleinschmit et al., (2006) found higher milk yield (34.6 vs.31.2 kg/day) in cows fed diets containing dried distillers grains and soluble.

Effect of inclusion of wet rice distiller's grain and soluble (WRDGS) in the diet significantly influenced the percentage of milk protein, total solid and solids not fat. The main effects of treatment did not affect the percentage of milk fat (3.76 vs. $3.77 \%$ ) when WRDGS was included in the ration, explanation of which was not apparent. The present finding is in agreement with Al-Suwaiegh et al., (2002) who showed similar milk fat percentage when wet and dry corn distiller's grain were used in dairy ration.
Milk protein percentage increased numerically (3.34 vs.3.32 and 3.35 vs.3.34) in the treatment group, however the effect was found to be non-significant $(\mathrm{P}>0.05)$. A depression effect for nonstructural carbohydrate on milk protein was observed due to the low availability of carbohydrates, immediate energy source for microbial protein synthesis and growth in the rumen (Spicer et al., 1986). Tessman et al., (1991) also demonstrated a decrease in milk protein by decreasing concentrate supplements in the diet. Palmquist and Moser (1981) suggested that fat inclusion in the diet may interfere with the insulin functions that influence amino acid transfer into the mammary gland, hence the decline in milk protein synthesis. Van Horn et al., (1985) observed a depression in milk protein percentage for cows fed DDGS from ethanol production relative to those fed soybean meal.

This effect was attributed to unavailable dietary protein and lower energy intake and unbalanced supply of amino acid particularly lysine in the DDGS diet. However, in the present study milk protein percentage was not affected which might be due to higher energy and protein content and balanced amino acids in rice distillers' grains. Schingoethe et al., (1999) and Birkelo et al., (2004) demonstrated a decrease in milk protein percentage in Holstein cows feeding wet corn distillers' grain whereas Kleinschmit et al., (2006) also reported the same by feeding various sources of DDGS.

No significant change of milk lactose percentage irrespective of feeding wet rice distiller's grain and soluble could be observed during $1^{\text {st }}$ and $2^{\text {nd }}$ month of experiment in both control and treatment groups. The present experiment corroborated with the results of Schingoethe et al., (1999) and Birkelo et al., (2004) who did not found any change in milk lactose percentage in Holstein cows by feeding wet corn distiller's grain. 
Table.1 Ingredients composition of concentrate diet for farm lactating dairy cows and their costs

\begin{tabular}{l|l|l|l|}
\hline Ingredients & Cost/kg $(\mathbf{R s})$ & Inclusion $(\mathbf{k g} / \mathbf{1 0 0 k g})$ & Total cost $(\mathbf{R s )}$ \\
\hline DORB & 9.00 & 42 & 378.00 \\
\hline Gram chuni & 18.00 & 15 & 270.00 \\
\hline Arhar chuni & 20.00 & 10 & 200.00 \\
\hline Crushed maize & 15.00 & 15 & 225.00 \\
\hline Pea husk & 13.00 & 15 & 195.00 \\
\hline Mineral mixture* & 70.00 & 2 & 140.00 \\
\hline Common salt & 5.00 & 1 & 5.00 \\
\hline $\begin{array}{l}\text { Total } \\
\text { * Each kg contains: CuSO4, 5H2O-15.3 g, ZnSO4, H2O-40.8 g, MnSO4, H2O-41.32 g, CoCl2, 6H2O-1.08 g, KI-62 } \\
\text { mg, and DCP-901.5 g }\end{array}$ & - & 100 & 1413.00 \\
\hline
\end{tabular}

Table.2 Performance of lactating dairy cows by feeding wet rice distiller's grain and soluble at farm level

\begin{tabular}{|c|c|c|c|c|c|}
\hline Items & Month & Control & Treatment & SEM & P Value \\
\hline \multirow{2}{*}{$\begin{array}{l}\text { Dry matter intake } \\
(\mathrm{kg}) / \text { day/anima }\end{array}$} & $1^{\mathrm{st}}$ & 9.04 & 8.42 & 0.121 & 0.002 \\
\hline & $2^{\text {nd }}$ & 8.98 & 8.47 & 0.113 & 0.011 \\
\hline \multirow{2}{*}{$\begin{array}{l}\text { Milk yield } \\
(\mathrm{kg}) / \text { day/anima }\end{array}$} & $1^{\mathrm{st}}$ & 8.55 & 8.65 & 0.130 & 0.724 \\
\hline & $2^{\text {nd }}$ & 8.70 & 8.85 & 0.094 & 0.461 \\
\hline \multicolumn{6}{|c|}{ Milk Composition (\%) } \\
\hline \multirow{2}{*}{ Fat } & $1^{\mathrm{st}}$ & 3.76 & 3.77 & 0.011 & 0.690 \\
\hline & $2^{\text {nd }}$ & 3.75 & 3.77 & 0.011 & 0.228 \\
\hline \multirow[t]{2}{*}{ Protein } & $1^{\text {st }}$ & 3.32 & 3.34 & 0.011 & 0.060 \\
\hline & $2^{\text {nd }}$ & 3.34 & 3.35 & 0.015 & 0.065 \\
\hline \multirow[t]{2}{*}{ Lactose } & $1^{\text {st }}$ & 4.47 & 4.47 & 0.007 & 0.869 \\
\hline & $2^{\text {nd }}$ & 4.47 & 4.46 & 0.011 & 0.617 \\
\hline \multirow{2}{*}{ Total Solid } & $1^{\mathrm{st}}$ & 12.13 & 12.21 & 0.023 & 0.004 \\
\hline & $2^{\text {nd }}$ & 12.14 & 12.25 & 0.028 & 0.735 \\
\hline \multirow[t]{2}{*}{ Solid Non Fat } & $1^{\mathrm{st}}$ & 8.38 & 8.44 & 0.023 & 0.021 \\
\hline & $2^{\text {nd }}$ & 8.39 & 8.49 & 0.029 & 0.456 \\
\hline \multirow[t]{2}{*}{ Ash } & $1^{\mathrm{st}}$ & 0.61 & 0.62 & 0.004 & 0.501 \\
\hline & $2^{\text {nd }}$ & 0.61 & 0.62 & 0.004 & 0.501 \\
\hline \multirow{2}{*}{$\begin{array}{l}\text { Feed cost } \\
\text { (Rs.)/day/animal }\end{array}$} & $1^{\mathrm{st}}$ & 109.04 & 100.46 & 0.806 & 0.001 \\
\hline & $2^{\text {nd }}$ & 108.34 & 100.56 & 0.777 & 0.003 \\
\hline \multirow{2}{*}{$\begin{array}{l}\text { Economic gain } \\
\text { (Rs)/day/animal }\end{array}$} & $1^{\text {st }}$ & - & 8.58 & - & - \\
\hline & $2^{\text {nd }}$ & - & 7.78 & - & - \\
\hline
\end{tabular}

Anderson et al., (2006) and Kleinschmit et al., (2006) also found similar findings by feeding various sources of wet and dry DGS in lactating dairy cows.
Total milk solid and solid not fat was significantly $(\mathrm{P}<0.05)$ varied in $1^{\text {st }}$ month of experiment but no change was observed in $2^{\text {nd }}$ month. Total solid percentage in treatment 
group (12.21 vs. 12.13) and SNF was also found higher (8.44 vs.8.38) in the $1^{\text {st }}$ month. It was not clear why only $1^{\text {st }}$ month of experimental period showed higher total solid and SNF percentage in treatment group. Haung et al., (1999) did not observe any change in solid not fat in Holstein cows fed $10 \%$ dried rice distiller's grain but slightly decrease in SNF \% when the inclusion level was $20 \%$. No significant change in milk ash percentage was observed both in control and treatment group.

The average feed cost for control and treatment groups were Rs. 108.64 and 100.46 for $1^{\text {st }}$ month and the same were Rs. 108.34 and 100.56 for $2^{\text {nd }}$ month. The economic gain per day per animal was Rs. 8.58 in $1^{\text {st }}$ month and Rs. 7.78 in $2^{\text {nd }}$ month when compared with control. It was concluded that wet rice cake can replace near about one-third portion of concentrate mixture without any adverse effect on milk yield, milk fat $\%$, milk protein, milk ash\% and lactose. Moreover, despite of less dry matter intake, wet rice cake (WRDGS) significantly influenced total solid and solid not fat. The economics of gain in terms of feed cost was comparable with control group.

\section{Acknowledgements}

Appreciation is extended to ICAR for providing all financial and laboratory support from AICRP on "Improvement of Feed Resources and Nutrient Utilization in Raising Animal Production" WBUAFS, Kolkata and Md. Chand for providing permission to conduct the research work at Ganganagar Dairy Farm, Dum Dum.

\section{References}

Al-Suwaiegh, S., Fanning, K.C., Grant, R. J., Milton, C. T. and T.J. Klopfenstein. (2002) Utilization of distillers grains from the fermentation of sorghum or corn in diets for finishing beef and lactating dairy cattle. J. Anim. Sci. 80:1105-1111.

Anderson, J.L; Schingoethe, D.J; Kalscheur K.F. and Hippen, A.R. (2006). Evaluation of dried and wet distillers' grains included at two concentrations in the diets of lactating dairy cows. $J$. Dairy Sci. 89: 3133-3142.

AOAC (1980). Official methods of analysis. Association of Official Analytical Chemist. 13 ${ }^{\text {th }}$ Ed., Post Box 540, Washington D.C., USA.

Birkelo, C.P; Brouk, M.J. and Schingoethe, D.J. (2004). The energy content of wet corn distillers grains for lactating dairy cows. J. Dairy Sci. 87:1815-1819.

Haung, H.J., Chiou, P.W.S., Chen, R.N., Chiang, J.K. and Yu, B. (1999). Effects of dried rice distiller's and grain supplementation on the performance of lactating cows. Animal Feed Science and Technology, 77:303-315.

Hippen, A. R., K.N. Linke; K. F. Kalscheur; D. J. Schingoethe and A. D. Gareia (2003). Increased concentration of wt distillers in dairy cow diets. J. Dairy Sci. 86(Suppl.1): 340(Abstr.)

ISI (1977) IS: 1224, Fat determination of whole milk, evaporated milk, separated milk, butter milk and cream by Garber method. Indian Standards Institution, Manak Bhavan, New Delhi.

ISI (1981), SP-18, Handbook of food analysis (Part XI), Dairy products. Indian Standards Institution, Manak Bhavan, New Delhi.

Kalscheur, K.F., Jastin A.L., Hippen, A.R. and Schingoethe, D.J. (2004). Increasing wet distiller's grains in diets of dairy cows on milk production and nutrient utilization. J. Dairy Sci., 87(Suppl. 1): 465. (Abstr.).

Kleinschmit, D.H; Schingoethe, D.J; Kalscheur, K.F and Hippen A.R (2006). 
Evaluation of various sources of corn distillers dried grains plus soluble (DDGS) for lactating dairy cattle. $J$. Dairy Sci. 89: 4784-4794.

Palmquist, D.L. and Moser, E.A. (1981). Dietary fat effects on blood insulin, glucose utilization and milk protein content of lactating cows. J. Dairy Sci., 64:1664-1670.

Perry, N.A. and Doan, F.J. (1950). A picric acid method for simultaneous determination of Lactose and Sucrose in Dairy Products. J. Dairy Sci., 33:176.

Powers, W.J; Van Horn, H.H; Harris, B.Jr. and Wilcox C.J (1995). Effects of variable sources of distillers dried grains plus soluble on milk yield and composition. J. Dairy Sci. 78: 388-396.

Schingoethe, D.J., Brouk, M.J. and Birkelo, C.P. (1999) Milk production and composition from cows fed wet corn distillers grains. J. Dairy. Sci., 82:574580.

Spicer, L.A., Theurer, C.B., Noon, T.H. (1986). Ruminal and post-ruminal utilization of nitrogen and starch from sorghum grain, corn and barley diets by beef steers. J. Anim. Sci., 62:521-530.

Tessman, N.J., Radloff, H.D., Kleinmans, J., Dhiman, T.R. and Satter L.D. (1991). Milk production response to dietary forage: grain ratio. J. Dairy Sci., 74:3583-3597.

Van Horn, H. H; O. Blanco; B. Harris, Jr. and D. K. Beede (1985). Interaction of protein percent with caloric density and protein source for lactating cows. $J$. Dairy Sci. 68:1682.

Warner, R.G. (1970). The place of distillers feeds in dairy rations-a review. Proc. Feed Res. Counc., 25, 11.

\section{How to cite this article:}

Pakhira, M.C. and Biswas, P. 2018. Effect of Wet Rice Distillers Grain and Solubles on Milk Production and Composition in Lactating Cows. Int.J.Curr.Microbiol.App.Sci. 7(09): 18451850. doi: https://doi.org/10.20546/ijcmas.2018.709.224 